\title{
Effective Remediation of Lead Ions from Aqueous Solution by Chemically Carbonized Rubber Wood Sawdust: Equilibrium, Kinetics, and Thermodynamic Study
}

\author{
Swarup Biswas ${ }^{1}$ and Umesh Mishra ${ }^{2}$ \\ ${ }^{1}$ Department of Environmental Engineering, NIT Agartala, Tripura 799046, India \\ ${ }^{2}$ Department of Civil Engineering, NIT Agartala, Tripura 799046, India \\ Correspondence should be addressed to Swarup Biswas; swarup.biswas85@gmail.com
}

Received 10 June 2015; Accepted 2 August 2015

Academic Editor: Wenshan Guo

Copyright (c) 2015 S. Biswas and U. Mishra. This is an open access article distributed under the Creative Commons Attribution License, which permits unrestricted use, distribution, and reproduction in any medium, provided the original work is properly cited.

\begin{abstract}
Rubber wood sawdust was carbonized into charcoal by chemical treatment which was used for removal of lead ion from aqueous solution. The work involves batch experiments to investigate the $\mathrm{pH}$ effect, initial concentration of adsorbate, contact time, and adsorbent dose. Experimental data confirmed that the adsorption capacities increased with increasing inlet concentration and bed height and decreased with increasing flow rate. Adsorption results showed a maximum adsorption capacity of $37 \mathrm{mg} / \mathrm{g}$ at $308 \mathrm{~K}$. Langmuir, Freundlich, and Temkin model adsorption isotherm models were applied to analyze the process where Temkin was found as a best fitted model for present study. Simultaneously kinetics of adsorption like pseudo-first-order, pseudo-second-order, and intraparticle diffusion models were investigated. Thermodynamic parameters were used to analyze the adsorption experiment. Fourier transform infrared spectroscopy, scanning electron microscope, and energy dispersive X-ray spectroscopy confirmed the batch adsorption of lead ion onto chemically carbonized rubber wood sawdust.
\end{abstract}

\section{Introduction}

Water pollution due to contamination of toxic lead ions is a serious problem for human health and environment. Lead discharged from petrochemical, organic, and inorganic fertilizer, oil refineries, and automobile industries contaminates the ground water and surface water $[1,2]$. According to the US Environmental Protection Agency (EPA), World Health Organization (WHO), and Indian Standard (IS), permissible limit of lead ion in drinking water is $0.015 \mathrm{mg} / \mathrm{L}, 0.01 \mathrm{mg} / \mathrm{L}$, and $0.05 \mathrm{mg} / \mathrm{L}$, respectively. Commercial methods such as filtration, chemical oxidation/reduction, electrochemical treatment, chemical precipitation, membrane separation, and ionexchange methods have been also utilized for the remediation of heavy metal contamination. Due to inefficiency and high operating cost these processes are not so much effective. Therefore in this study we adopted adsorption process for removal of lead ion. Many biosorbents, for example, Caulerpa lentillifera [3], sago waste [4], sawdust [5], jute [5], coir [6], algae [7], waste tea leaves [8], ground nut shell [5], rice husk ash [9], and papaya wood [10], were previously investigated by various researchers for removal of lead ions.

In this study chemically carbonized rubber wood sawdust (CCRWSD) was utilized for removal of lead ions from synthetic wastewater. The $\mathrm{pH}$ effect, initial concentration, contact time, and adsorbent dose in batch mode were investigated. In addition isotherm, kinetic, and thermodynamic study were carried out to compare the experimental data and to understand the adsorption behavior of lead ion onto CCRWSD.

\section{Materials and Methods}

2.1. Preparation of Biomass. Rubber wood sawdust was collected from rubber wood processing industry, Nagechera, Tripura, India. The carbonization and activation were done in two steps, where in first step rubber wood sawdust (10 gm) was added in concentrated sulphuric acid $(11 \mathrm{~mL}, 98 \% \mathrm{~m} / \mathrm{m})$ 


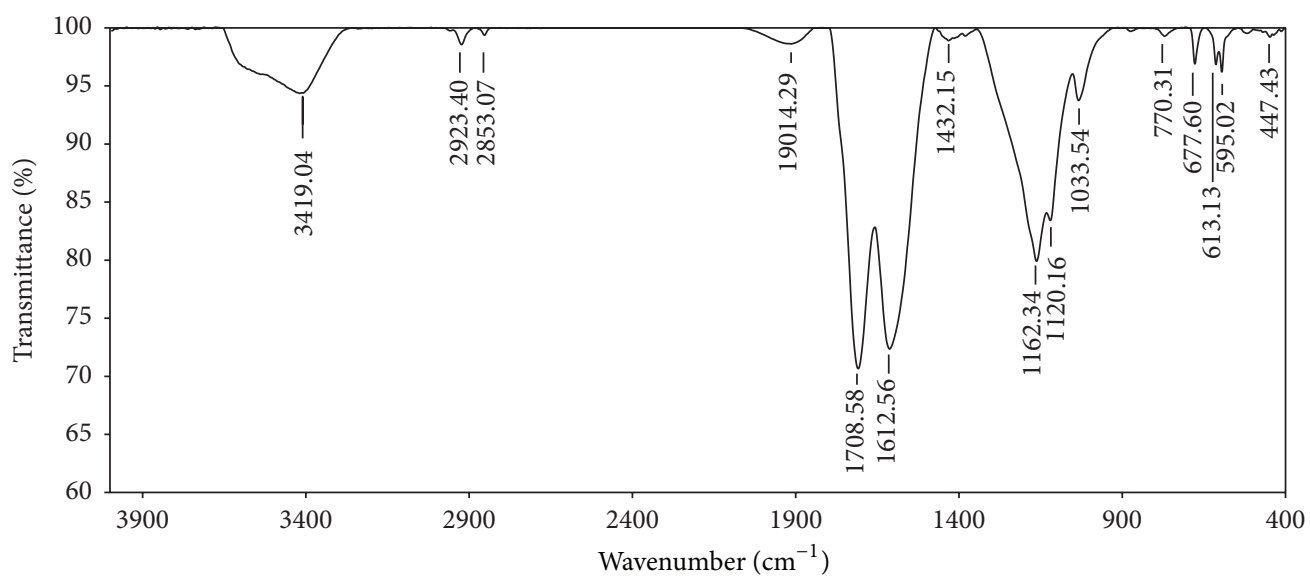

FIGURE 1: FTIR spectra of CCRWSD.

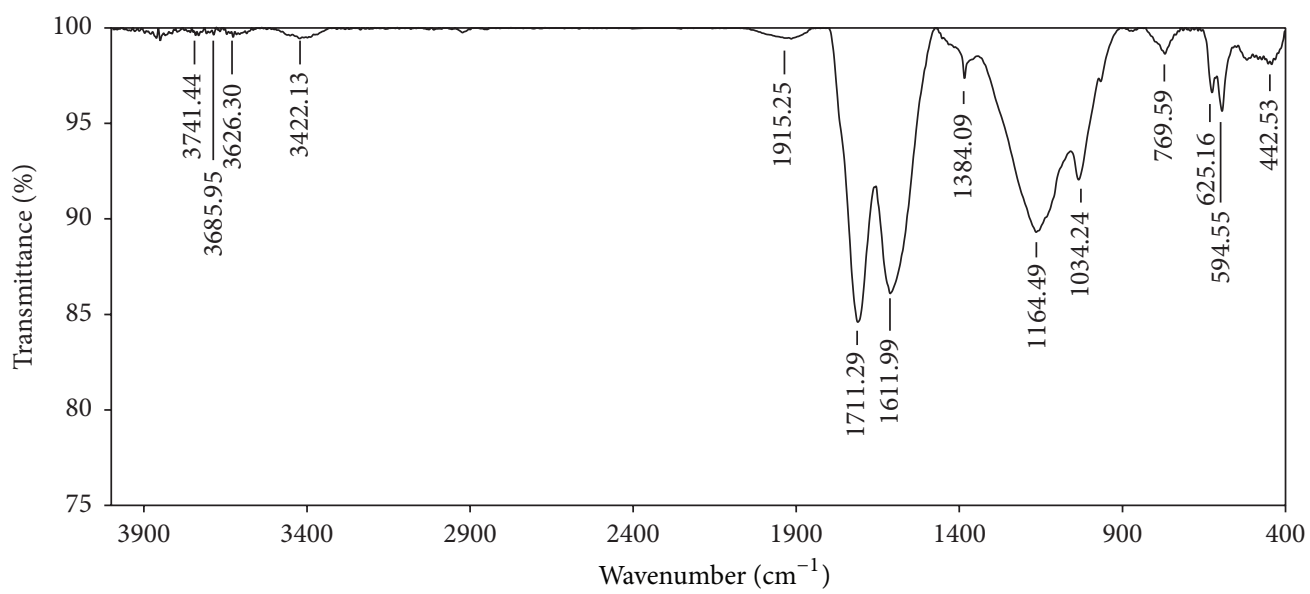

FIGURE 2: FTIR spectra of lead ion loaded CCRWSD.

for carbonization and kept for 10 minutes. Then in second step carbonized black slurry was mixed with concentrated nitric acid $(6.6 \mathrm{~mL}, 65 \% \mathrm{~m} / \mathrm{m})$ and kept in air oven at $150^{\circ} \mathrm{C}$ for 24 hours. Carbonized sawdust was centrifuged with deionized water until the $\mathrm{pH}$ became neutral and dried in $110 \pm 2^{\circ} \mathrm{C}$. Screening of the dried CCRWSD was done to get desired particle sizes ranging from 0.5 to $1 \mathrm{~mm}$.

2.2. Characterization of the Adsorbent. Atomic absorption spectrophotometer (Perkin Elmer Model AAS 700) was utilized to determine the lead concentration in effluent and influent samples. Fourier transform infrared spectroscopy (FTIR) (Bruker 3000 Hyperion, Germany) was used to study the functional group present in adsorbent. Scanning electron microscope (SEM) (JELO JSM7600F) supported by EDS (energy dispersive X-ray spectroscopy) (Oxford AZtech energy system) was utilized to characterize the surface of adsorbent.

2.3. Batch Experiment. Batch experiment was carried out in a thermostatically controlled magnetic stirrer at $30^{\circ} \mathrm{C}$ with the speed of $120 \mathrm{rpm}$. A $0.5 \mathrm{~g}$ of CCRWSD was utilized at different concentration $(5 \mathrm{mg} / \mathrm{L}$ to $30 \mathrm{mg} / \mathrm{L})$ and at different $\mathrm{pH}(2.1$ to 6.8). The experiment was done at different adsorbent dose $(0.25 \mathrm{~g} / \mathrm{L}$ to $5 \mathrm{~g} / \mathrm{L})$. For thermodynamic study the adsorption experiment was conducted in three different temperatures $(303 \mathrm{~K}, 313 \mathrm{~K}$, and $323 \mathrm{~K})$. After completing every batch experiment the solution was filtered and sample was tested to know the residual lead concentration.

\section{Results and Discussion}

3.1. Characterization of the Adsorbent. Before and after adsorption functional groups were identified by using FTIR in the range of $400-4000 \mathrm{~cm}^{-1}$ as shown in Figures 1 and 2. In CCRWSD the peak at $1708.58 \mathrm{~cm}^{-1}$ and $1612.56 \mathrm{~cm}^{-1}$ shows the presence of $\mathrm{C}=\mathrm{O}$ group and $-\mathrm{COO}^{-}$group. Another major peak is observed at $1162.34 \mathrm{~cm}^{-1}$ which is due to $\mathrm{C}-\mathrm{O}$ group. The peak at $3419 \mathrm{~cm}^{-1}$ is due to $\mathrm{O}-\mathrm{H}$ stretch from carboxyl group $(\mathrm{O}=\mathrm{C}-\mathrm{OH}$ and $\mathrm{C}-\mathrm{OH})$ and peak $2923.40 \mathrm{~cm}^{-1}$ represents the presence of $\mathrm{O}-\mathrm{H}$ stretch (hydrogen bonded - $\mathrm{COOH}$ ). Important fact is that the shifting of peaks is observed after adsorption of lead ion which is a strong evidence of adsorption in the CCRWSD. After adsorption 


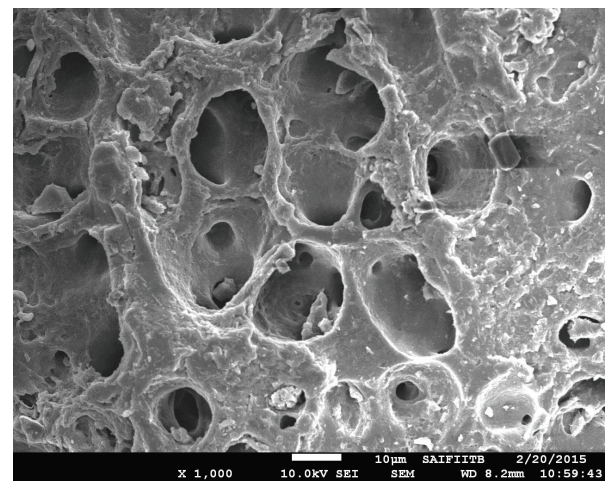

FIGURE 3: SEM image of CCRWSD.

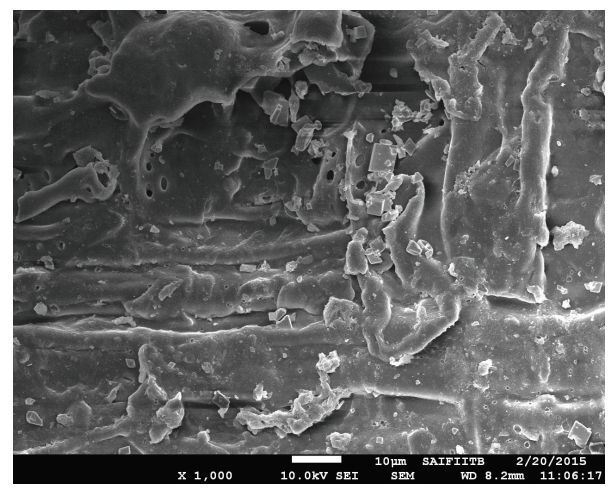

FIGURE 4: SEM image of lead ion loaded CCRWSD.

of lead ion, peaks are shifted because carboxyl and hydroxyl group may release proton and form new complexes with lead ion. SEM analysis (Figures 3 and 4) suggests the change in surface structure before and after adsorption of lead ion. On the other hand, EDS results also confirm the feasibility of lead adsorption process (Figures 5 and 6).

3.2. Batch Result Analysis. Adsorption capacity is increased with the increasing of solution $\mathrm{pH}$ from 2.1 to 5.6 and then starts to decrease with increasing $\mathrm{pH}$ as shown in Figure 7. At low $\mathrm{pH}$ adsorption capacity is low because of higher concentration of $\mathrm{H}^{+}$ion in the solution which occupies the binding sites of adsorbent.

Effect of contact time on adsorption of lead ion onto CCRWSD is shown in Figure 8. It is observed that the rapid adsorption is taking place in first half an hour and thereafter rate of lead ion adsorption decreases. After some time period of adsorption surface sites are occupied by lead ion and adsorption process decreases.

It is found that adsorption capacity increases from 9.82 to $36.4 \mathrm{mg} / \mathrm{g}$ with the increase in initial lead ion concentration from 5 to $30 \mathrm{mg} / \mathrm{L}$. At lower concentration maximum adsorption sites are available for adsorption of lead ion. On the other hand at higher concentration many lead ions left unabsorbed in the solution as the entire binding site get saturated by lead ion.

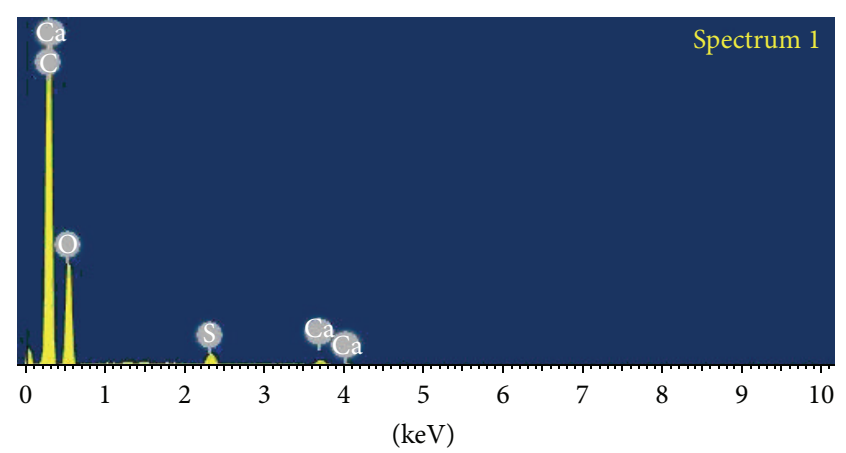

Full scale 14190 cts. cursor: 0.000

FIGURE 5: EDS spectra of CCRWSD.

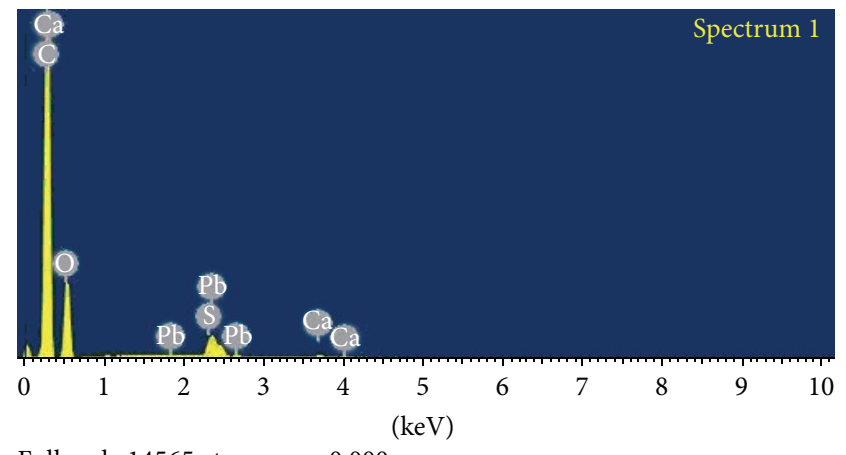

Full scale 14565 cts. cursor: 0.000

FIGURE 6: EDS spectra of lead ion loaded CCRWSD.

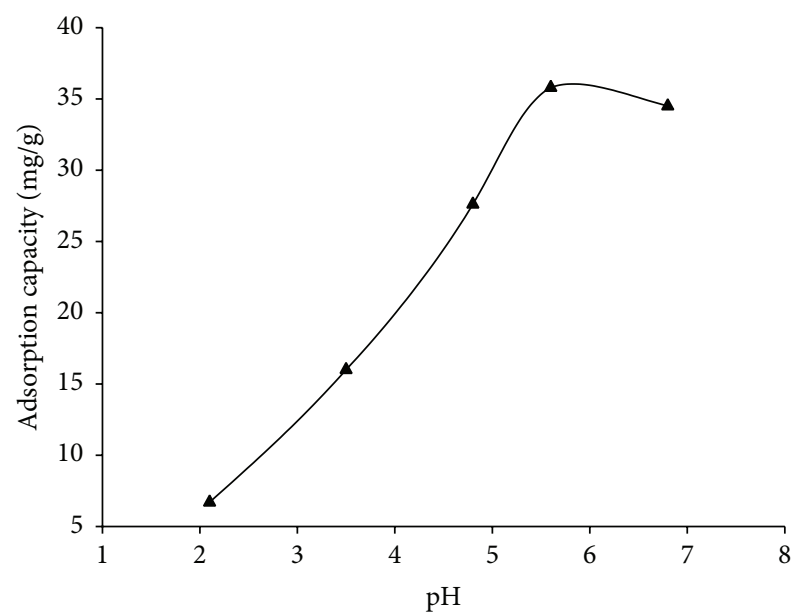

FIGURE 7: Effect of $\mathrm{pH}$ on the adsorption of lead ions onto CCRWSD $\left(C_{0}=20 \mathrm{mg} / \mathrm{L}\right.$, dose $=0.5 \mathrm{~g} / \mathrm{L}$, contact time $=120 \mathrm{~min}$, and temperature $=30^{\circ} \mathrm{C}$ ).

Adsorption capacity increases from $3.96 \mathrm{mg} / \mathrm{g}$ to $37 \mathrm{mg} / \mathrm{g}$ with the decreasing of adsorbent dose from $5 \mathrm{~g} / \mathrm{L}$ to $0.25 \mathrm{~g} / \mathrm{L}$. As binding sites of adsorbent increase with the increasing adsorbent amount the removal percentage increases.

3.3. Adsorption Isotherms. In batch adsorption process, Langmuir, Freundlich, Temkin, and Dubinin-Radushkevich 
TABLE 1: Parameters of Langmuir, Freundlich, and Temkin adsorption isotherm constants for adsorption of lead onto CCRWSD.

\begin{tabular}{lccccccc}
\hline \multicolumn{2}{c}{ Langmuir } & \multicolumn{2}{c}{ Freundlich } & \multicolumn{2}{c}{ Temkin } & \multicolumn{2}{c}{ Dubinin-Radushkevich } \\
\hline$Q_{m}(\mathrm{mg} / \mathrm{g})$ & 41.15 & $K_{F}(\mathrm{mg} / \mathrm{g})$ & 27.63 & $B$ & 8.16 & $q_{m}(\mathrm{mg} / \mathrm{g})$ & 32.06 \\
$B(\mathrm{~L} / \mathrm{mg})$ & 2.73 & $n$ & 2.44 & $b(\mathrm{~J} / \mathrm{mol})$ & 308.76 & $\beta\left(\mathrm{mol}^{2} \mathrm{~J}^{2}\right)$ & 0.0031 \\
$R_{L}$ & $0.859-0.960$ & $R^{2}$ & 0.988 & $A(\mathrm{~L} / \mathrm{g})$ & 34.1 & $E(\mathrm{~kJ} / \mathrm{mol})$ & 12.70 \\
$R^{2}$ & 0.992 & & & $R^{2}$ & 0.993 & $R^{2}$ & 0.954 \\
\hline
\end{tabular}

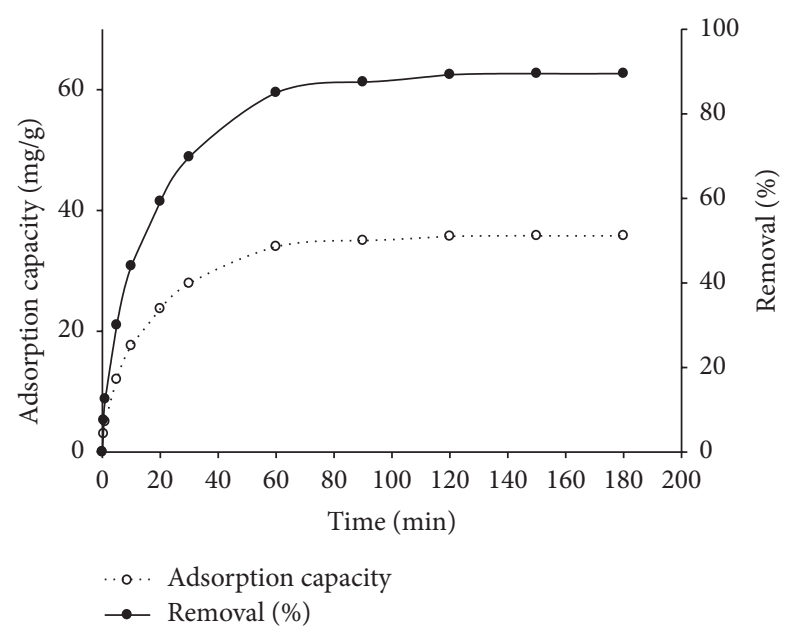

FIGURE 8: Effect of contact time on the adsorption of lead ions onto CCRWSD $\left(C_{0}=20 \mathrm{mg} / \mathrm{L}\right.$, dose $=0.5 \mathrm{~g} / \mathrm{L}, \mathrm{pH}=5.6$, and temperature $\left.=30^{\circ} \mathrm{C}\right)$.

(D-R) isotherm models were utilized to describe the equilibrium data.

Langmuir adsorption isotherm [11] equation is expressed as

$$
\frac{C_{e}}{q_{e}}=\frac{1}{b Q_{m}}+\frac{C_{e}}{Q_{m}},
$$

where $q_{e}(\mathrm{mg} / \mathrm{g})$ is the amount of lead adsorbed at equilibrium, $C_{e}(\mathrm{mg} / \mathrm{L})$ is the equilibrium concentration of lead ion in solution, $b(\mathrm{~L} / \mathrm{mg})$ is the Langmuir constant, and $Q_{m}$ $(\mathrm{mg} / \mathrm{g})$ is the maximum adsorption amount of lead ion per unit weight of adsorbent to form a complete monolayer on the surface bound at $C_{e}$. The values of $Q_{m}$ and $b$ are calculated from the slopes and intercepts of linear plots of $C_{e} / q_{e}$ versus $C_{e}$ (Figure 9) and are illustrated in Table 1.

Langmuir isotherm can be checked by the value of $R_{L}$ (2) [12] as isotherm is irreversible $\left(R_{L}=0\right)$, favorable $\left(0<R_{L}<\right.$ $1)$, linear $\left(R_{L}=1\right)$, or unfavorable $\left(R_{L}>1\right)$ :

$$
R_{L}=\frac{1}{1+b C_{0}}
$$

where $C_{0}(\mathrm{mg} / \mathrm{L})$ and $b(\mathrm{~L} / \mathrm{mg})$ are denoted by initial concentration of lead ion and Langmuir constant. In experiment $R_{L}$ values are found to be $0.859-0.960$ which indicates the favorable lead adsorption.

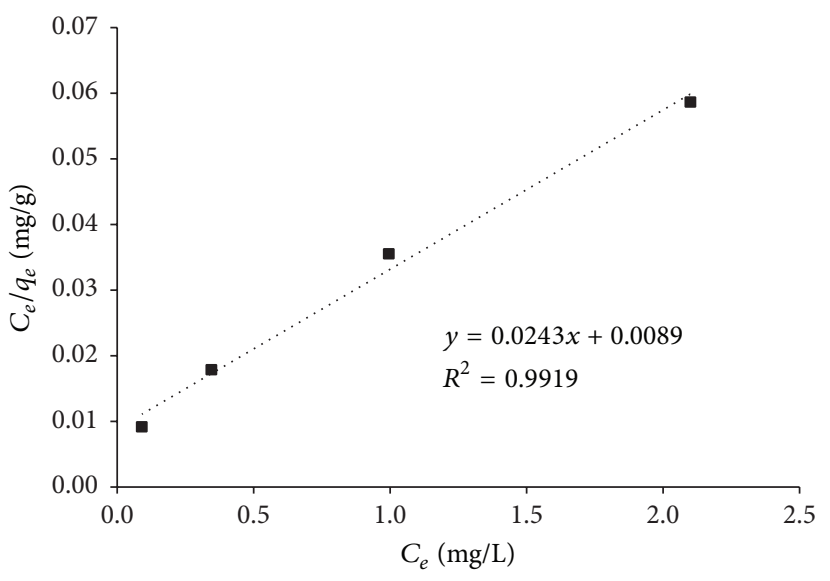

Figure 9: Langmuir isotherm $\left(\mathrm{pH}=5.6, C_{0}=5-20 \mathrm{mg} / \mathrm{L}\right.$, dose $=$ $0.5 \mathrm{~g} / \mathrm{L}$, contact time $=180 \mathrm{~min}$, and temperature $=30^{\circ} \mathrm{C}$ ).

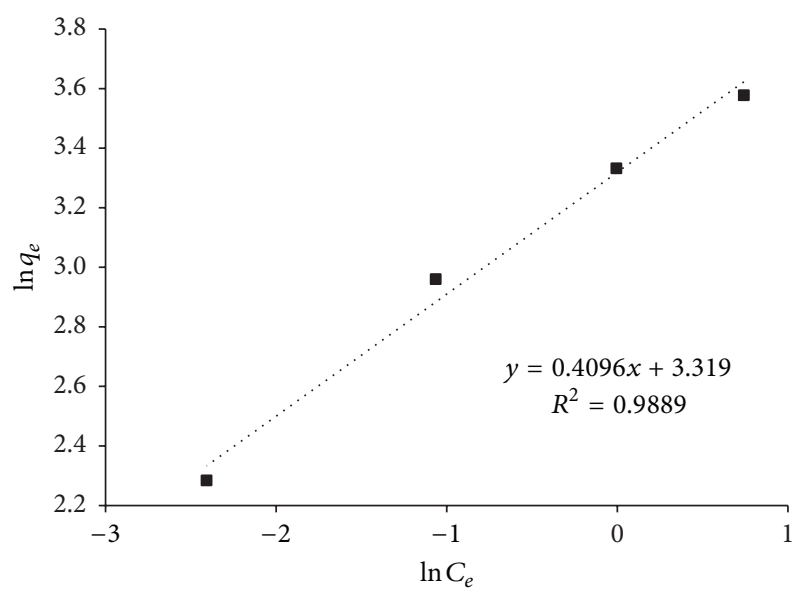

FIgURE 10: Freundlich isotherm $\left(\mathrm{pH}=5.6, C_{0}=5-20 \mathrm{mg} / \mathrm{L}\right.$, dose $=$ $0.5 \mathrm{~g} / \mathrm{L}$, contact time $=180 \mathrm{~min}$, and temperature $=30^{\circ} \mathrm{C}$ ). [13]

Linear form of the Freundlich isotherm is expressed as

$$
\ln q_{e}=\ln K_{F}+\frac{1}{n} \ln C_{e},
$$

where $K_{F}$ and $n$ are known as Freundlich coefficients, $q_{e}$ $(\mathrm{mg} / \mathrm{g})$ is the amount of lead ion adsorbed, and $C_{e}(\mathrm{mg} / \mathrm{L})$ is the concentration of lead solution at equilibrium. For applying Freundlich model, $C_{e}$ is plotted against $C_{e} / q_{e}$ (Figure 10) which gives the value of $K_{F}$ and $n$. The values of the Freundlich coefficients and the correlation coefficients $R^{2}$ are 


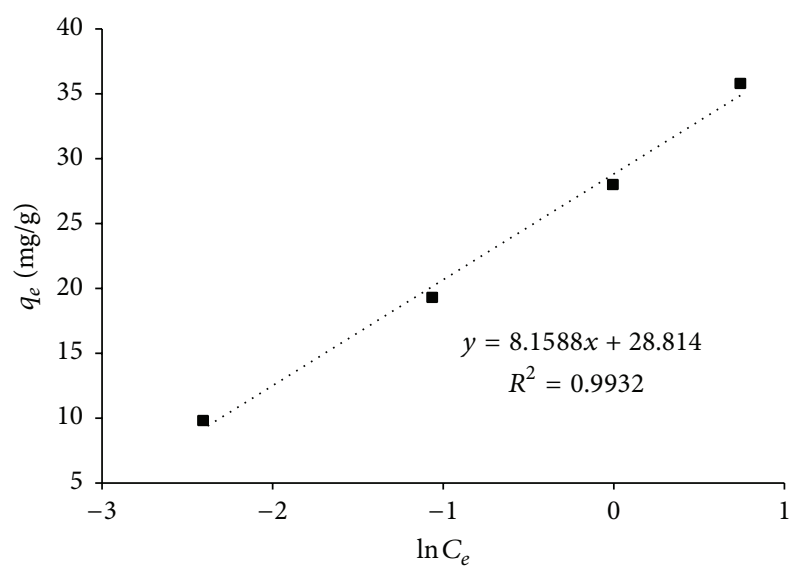

FIgure 11: Temkin isotherm $\left(\mathrm{pH}=5.6, C_{0}=5-20 \mathrm{mg} / \mathrm{L}\right.$, dose $=$ $0.5 \mathrm{~g} / \mathrm{L}$, contact time $=180 \mathrm{~min}$, and temperature $=30^{\circ} \mathrm{C}$ ).

explained in Table 1 . The value of $n$ is 2.44 for lead adsorption on CCRWSD. As the value of $n$ lies between 1 and 10, it can be concluded that Freundlich model is favorable for lead adsorption studies.

Temkin isotherm model is generally expressed as [14]

$$
q_{e}=B \ln A+B \ln C_{e} .
$$

$B$ is expressed as $R T / b$, where $b(\mathrm{~J} / \mathrm{mol})$ is the Temkin constant and $T(\mathrm{~K})$ is the absolute temperature in Kelvin. $R$ $(8.314 \mathrm{~J} / \mathrm{mol} \mathrm{K})$ is the gas constant and $A(\mathrm{~L} / \mathrm{g})$ is the Temkin isotherm constant. The plot of $q_{e}$ versus $\ln C_{e}$ (Figure 11) gives the values of $B, b$, and $A$. The values of the Temkin constants $(b)$ and correlation coefficients $\left(R^{2}\right)$ are shown in Table 1. Value of $R^{2}$ is greater than 0.99 which justifies that model is well fitted for adsorption of lead ion on the surface of CCRWSD.

Linearized form of Dubinin-Radushkevich isotherm equation [15] is expressed as

$$
\ln q_{e}=\ln q_{m}-\beta \varepsilon^{2},
$$

where $q_{e}(\mathrm{mg} / \mathrm{g})$ is the number of lead ions adsorbed per unit weight of CCRWSD, $q_{m}(\mathrm{mg} / \mathrm{g})$ is the maximum adsorption capacity, and $\beta\left(\mathrm{mol}^{2} \mathrm{~J}^{2}\right)$ is the activity coefficient.

$E(\mathrm{~kJ} / \mathrm{mol})$ is the adsorption energy and $\varepsilon$ is the Polanyi potential. $\varepsilon$ is expressed as

$$
\varepsilon=R T \ln \left(1+\frac{1}{C_{e}}\right),
$$

where $R(\mathrm{~J} / \mathrm{molK})$ and $T(\mathrm{~K})$ are the gas constant and temperature. The plot of $\ln q_{e}$ versus $\varepsilon^{2}$ (Figure 12) gives the value of $b\left(\mathrm{~mol}^{2} / \mathrm{J}^{2}\right)$ and $q_{e}(\mathrm{mg} / \mathrm{g})$. The equation which is used for the calculation of adsorption energy is expressed as

$$
E=\frac{1}{\sqrt{2 \beta}} \text {. }
$$

These parameters give the information about sorption mechanism, either chemical ion-exchange or physical sorption. D-R parameters are calculated from the plot of $\ln q_{e}$

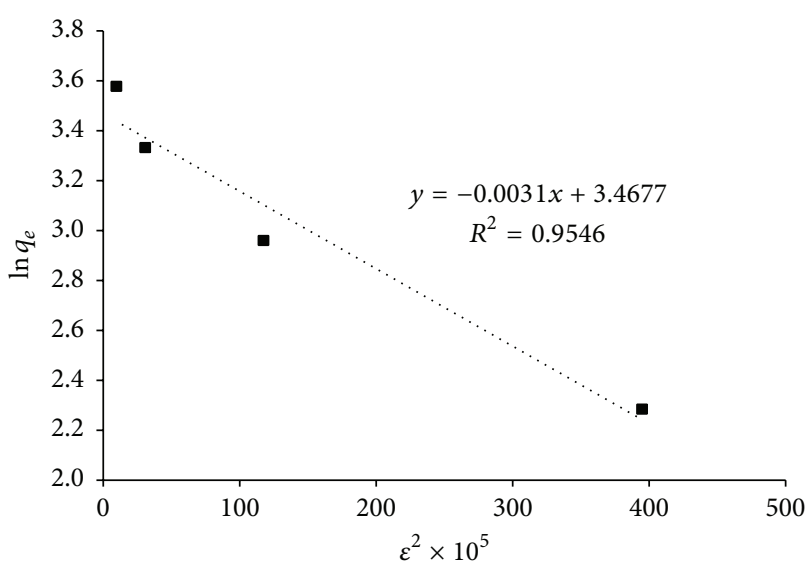

Figure 12: D-R isotherm $\left(\mathrm{pH}=5.6, C_{0}=5-20 \mathrm{mg} / \mathrm{L}\right.$, dose $=0.5 \mathrm{~g} / \mathrm{L}$, contact time $=180 \mathrm{~min}$, and temperature $=30^{\circ} \mathrm{C}$ ).

versus $\varepsilon^{2} \times 10^{5}$ and listed in Table 1 . From calculation it is found that the value of adsorption energy $E$ is $12.70 \mathrm{~kJ} / \mathrm{mol}$. The value of adsorption energy is greater than $8 \mathrm{~kJ} / \mathrm{mol}$ and smaller than $16 \mathrm{~kJ} / \mathrm{mol}$ which indicates chemisorption phenomenon [16].

After calculation of all isotherms it is observed that the value of correlation coefficients $\left(R^{2}\right)$ for Temkin model is higher than the other isotherms from which it can be concluded that Temkin model is the best fitted model for this adsorption process. Langmuir, Freundlich, and DubininRadushkevich are also well fitted models for the present system; hence the adsorption process can be described by these models also. In Langmuir model maximum adsorption capacity $\left(Q_{m}\right)$ at monolayer is measured whereas DubininRadushkevich deals with the maximum adsorption capacity $\left(q_{m}\right)$ at microspores volume of CCRWSD (Table 1). As a result value of the adsorption capacity from Langmuir model is higher than the Dubinin-Radushkevich model. Furthermore, high value of $b(\mathrm{~L} / \mathrm{mg})$ indicates that there is a strong interaction between the functional group of the adsorbent and lead ion which leads to an efficient adsorption process.

3.4. Adsorption Kinetics. Adsorption kinetic studies were conducted to have a better and broader understanding of the dynamic behaviour of lead adsorption onto CCRWS. Pseudofirst-order, pseudo-second-order, and intraparticle diffusion models are applied to study the adsorption process.

Pseudo-first-order model [17] is expressed as

$$
\log \left(q_{e}-q_{t}\right)=\left(\log q_{e}\right)-\left(\frac{k_{1}}{2.303}\right) t,
$$

where $q_{t}(\mathrm{mg} / \mathrm{g})$ and $q_{e}(\mathrm{mg} / \mathrm{g})$ are the amount of lead ions adsorbed at time $t(\mathrm{~min})$ and at equilibrium per unit weight of the adsorbent. $q_{t}(\mathrm{mg} / \mathrm{g})$ is the amount of lead ion adsorbed at any time and $k_{1}\left(\mathrm{~min}^{-1}\right)$ is the pseudo-first-order rate constant. The plot of $\log \left(q_{e}-q_{t}\right)$ versust (not shown in figure) at different concentration gives the values of $k_{1}$ and $q_{e}$.

The values of $k_{1}$ and $q_{e}$ are shown in Table 2, where values of $q_{e}$ are quite similar with experimental data and 
TABLE 2: A pseudo-first-order, pseudo-second-order, and intraparticle diffusion model parameter for adsorption of lead ion onto CCRWSD

\begin{tabular}{lcccc}
\hline \multirow{2}{*}{ Constants } & \multicolumn{4}{c}{ Initial concentration $(\mathrm{mg} / \mathrm{L})$} \\
& 5 & 10 & 15 & 20 \\
\hline$q_{\text {e exp. }}(\mathrm{mg} / \mathrm{g})$ & 9.82 & 19.31 & 28.05 & 35.8 \\
Pseudo-first order & & & & \\
$\quad q_{\text {e cal }}(\mathrm{mg} / \mathrm{g})$ & 7.58 & 16.52 & 27.29 & 31.87 \\
$\quad k_{1}\left(\mathrm{~min}^{-1}\right)$ & 0.0283 & 0.0377 & 0.0301 & 0.0458 \\
$R^{2}$ & 0.991 & 0.995 & 0.984 & 0.990 \\
Pseudo-second order & & & & \\
$\quad q_{\text {cal }}\left(\mathrm{mg}^{2}\right)$ & 10.12 & 2.02 & 3.26 & 37.45 \\
$k_{2}\left(\mathrm{~g} \mathrm{mg}^{-1} \mathrm{~min}^{-1}\right)$ & 0.016 & 0.600 & 0.199 & 0.004 \\
$R^{2}$ & 0.998 & 0.995 & 0.988 & 0.998 \\
Intraparticle diffusion & & & & \\
$\quad k_{\text {id }}\left(\mathrm{g} \mathrm{mg}^{-1} \mathrm{~min}^{-1}\right)$ & 0.709 & 1.488 & 2.294 & 2.763 \\
$R^{2}$ & 0.873 & 0.895 & 0.926 & 0.872 \\
\hline
\end{tabular}

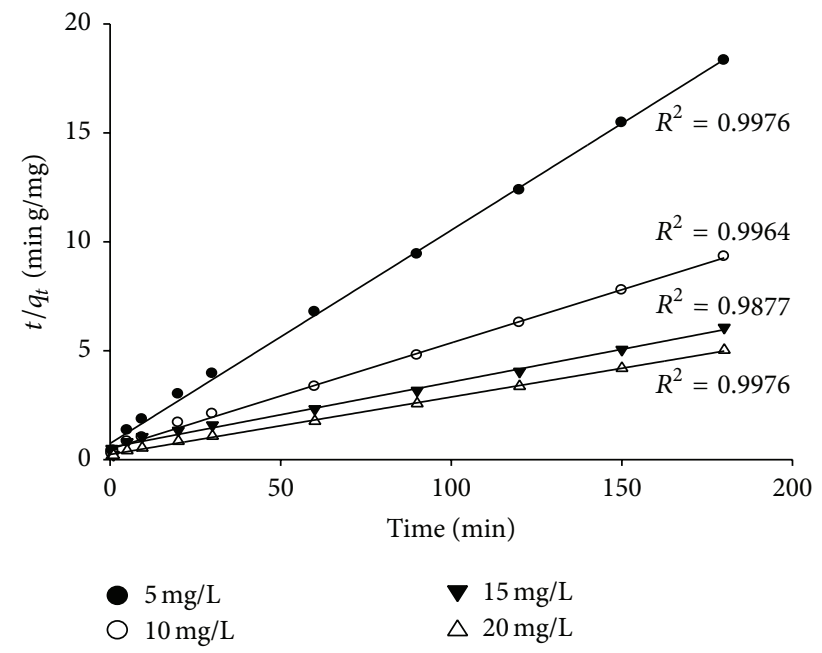

Figure 13: Pseudo-second-order model $(\mathrm{pH}=5.6$, dose $=0.5 \mathrm{~g} / \mathrm{L}$, contact time $=180 \mathrm{~min}$, and temperature $=30^{\circ} \mathrm{C}$ ).

values of $R^{2}$ are close to the unity. Similarities indicate the better agreement of pseudo-first-order model with the experimental data.

Pseudo-second-order model [18] is expressed as

$$
\frac{t}{q_{t}}=\left(\frac{1}{k_{2} q_{e}^{2}}\right)+\left(\frac{1}{q_{e}}\right) t
$$

where $k_{2}(\mathrm{~g} / \mathrm{mg} \min )$ is the pseudo-second-order rate constant. $q_{e}(\mathrm{mg} / \mathrm{g})$ and $q_{t}(\mathrm{mg} / \mathrm{g})$ are the maximum capacity at equilibrium and at time $t(\mathrm{~min})$. Values of $k_{2}(\mathrm{~g} / \mathrm{mg} \mathrm{min})$ and $q_{e}(\mathrm{mg} / \mathrm{g})$ are determined by using the plot of $t / q_{t}$ versus $t$ (Figure 13). The results are shown in Table 2 where values of theoretical adsorption capacities are not closer to the experimental data which concludes that the pseudo-secondorder model is not suitable to explain the kinetics of the present adsorption system.

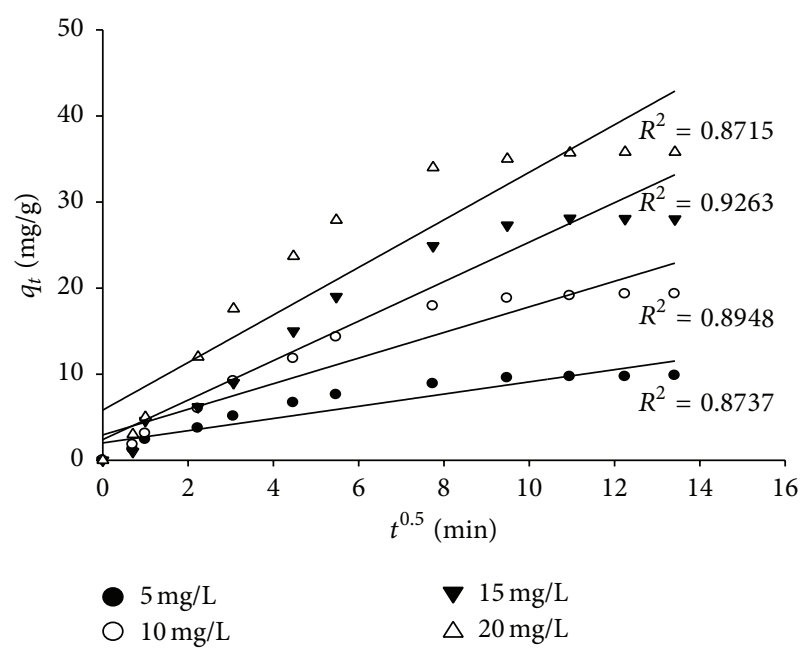

Figure 14: Intraparticle diffusion model $(\mathrm{pH}=5.6$, dose $=0.5 \mathrm{~g} / \mathrm{L}$, contact time $=180 \mathrm{~min}$, and temperature $=30^{\circ} \mathrm{C}$ ).

Adsorption process is also checked by applying intraparticle diffusion model which is expressed as [19]

$$
q_{t}=k_{i} t^{0.5}+C
$$

where $k_{i}(\mathrm{mg} / \mathrm{g} \mathrm{min})$ is the intraparticle diffusion constant. The plot of $q_{t}$ versus $t^{0.5}$ (Figure 14) gives the values of $k_{i}$.

Results of the model are summarized in Table 2, where it can be seen that the values of $R^{2}$ for intraparticle diffusion model are lower than the other models. So intraparticle diffusion model is not sufficient to explain the present system.

3.5. Thermodynamic Study. Thermodynamic study of lead ion adsorption by CCRWSD was conducted in three different temperatures $(303,313$, and $323 \mathrm{~K})$. Gibbs free energy $(\Delta G)$ $(\mathrm{kJ} / \mathrm{mol})$ of adsorption can be calculated by using (11) and (12) [20]. Enthalpy change $(\Delta H)(\mathrm{kJ} / \mathrm{mol})$ and entropy change $(\Delta S)(\mathrm{J} / \mathrm{K} \mathrm{mol})$ are also the most important thermodynamic parameters which influence the adsorption process and they can be calculated by using (13) and (14) [20]:

$$
\begin{aligned}
\Delta G & =-R T \ln K_{d}, \\
K_{d} & =\frac{q_{e}}{C_{e}}, \\
\ln K_{d} & =\frac{\Delta S}{R}-\frac{\Delta H}{R T}, \\
\Delta G & =\Delta H-T \Delta S,
\end{aligned}
$$

where $R$ denotes gas constant, $q_{e}(\mathrm{mg} / \mathrm{g})$ is the adsorption capacity at equilibrium, and $C_{e}(\mathrm{mg} / \mathrm{L})$ is the concentration at equilibrium at absolute temperature $T(\mathrm{~K})$. The slope and intercept of $\ln K_{d}$ versus $1 / T$ give (Figure 15) the value of $\Delta H$ and $\Delta S$.

A summary of calculated thermodynamic parameter is given in Table 3. The negative values of $\Delta G$ for lead ion adsorption indicate that the process is spontaneous and positive value of $\Delta H(+10.474 \mathrm{~kJ} / \mathrm{mol})$ is an indication of 


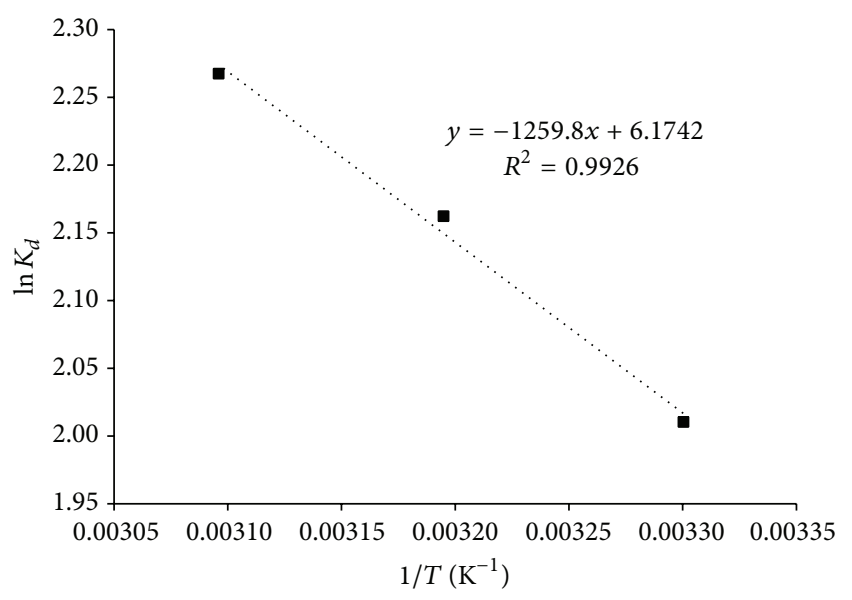

FIGURE 15: Thermodynamic plot for adsorption of lead ions onto CCRWSD $(\mathrm{pH}=5.6$, dose $=0.5 \mathrm{~g} / \mathrm{L}$, contact time $=180 \mathrm{~min}$, and concentration $=20 \mathrm{mg} / \mathrm{L}$ ).

TABLE 3: Thermodynamic parameters for lead adsorption $(\mathrm{pH}=$ 5.6 , dose $=0.5 \mathrm{~g} / \mathrm{L}$, contact time $=180 \mathrm{~min}$, and concentration $=$ $20 \mathrm{mg} / \mathrm{L})$.

\begin{tabular}{lccc}
\hline$T(\mathrm{~K})$ & $\Delta H(\mathrm{~kJ} / \mathrm{mol})$ & $\Delta S(\mathrm{~J} / \mathrm{K} \mathrm{mol})$ & $\Delta G(\mathrm{~kJ} / \mathrm{mol})$ \\
\hline 303 & +10.474 & +51.332 & -5.064 \\
313 & & & -5.627 \\
323 & & & -6.089 \\
\hline
\end{tabular}

endothermic process. Positive value of $\Delta S(+51.332 \mathrm{~J} / \mathrm{K} \mathrm{mol})$ reflects the randomness at solid solution interface.

\section{Conclusions}

CCRWSD was found as a feasible adsorbent medium with maximum adsorption capacity of $37 \mathrm{mg} / \mathrm{g}$ in batch mode. The adsorption capacity is greatly affected by the $\mathrm{pH}$ of sample solution and its concentration. Batch experimental data shows a good agreement with Temkin isotherm model and the pseudo-first-order kinetic model. For low cost and high adsorption capacity CCRWS would be a good promising adsorbent for lead contaminated wastewater treatment.

\section{Conflict of Interests}

The authors declare that there is no conflict of interests regarding the publication of this paper.

\section{Acknowledgment}

The authors are thankful to Director of National Institute of Technology Agartala for providing necessary research facilities.

\section{References}

[1] S. H. Abdel-Halim, A. M. A. Shehata, and M. F. El-Shahat, "Removal of lead ions from industrial waste water by different types of natural materials," Water Research, vol. 37, no. 7, pp. 1678-1683, 2003.

[2] G. Uzu, S. Sobanska, G. Sarret, J. J. Sauvain, P. Pradère, and C. Dumat, "Characterization of lead-recycling facility emissions at various workplaces: major insights for sanitary risks assessment," Journal of Hazardous Materials, vol. 186, no. 2-3, pp. 1018-1027, 2011.

[3] R. Apiratikul and P. Pavasant, "Batch and column studies of biosorption of heavy metals by Caulerpa lentillifera," Bioresource Technology, vol. 99, no. 8, pp. 2766-2777, 2008.

[4] S. Y. Quek, D. A. J. Wase, and C. F. Forster, "The use of sago waste for the sorption of lead and copper," Water SA, vol. 24, no. 3, pp. 251-256, 1998.

[5] S. R. Shukla and R. S. Pai, "Removal of Pb(II) from solution using cellulose-containing materials," Journal of Chemical Technology and Biotechnology, vol. 80, no. 2, pp. 176-183, 2005.

[6] K. Conrad and H. C. B. Hansen, "Sorption of zinc and lead on coir," Bioresource Technology, vol. 98, no. 1, pp. 89-97, 2007.

[7] A. Kapoor, T. Viraraghavan, and D. R. Cullimore, "Removal of heavy metals using the fungus Aspergillus niger," Bioresource Technology, vol. 70, no. 1, pp. 95-104, 1999.

[8] S. S. Ahluwalia and D. Goyal, "Removal of heavy metals by waste tea leaves from aqueous solution," Engineering in Life Sciences, vol. 5, no. 2, pp. 158-162, 2005.

[9] Q. Feng, Q. Lin, F. Gong, S. Sugita, and M. Shoya, "Adsorption of lead and mercury by rice husk ash," Journal of Colloid and Interface Science, vol. 278, no. 1, pp. 1-8, 2004.

[10] A. Saeed, M. W. Akhter, and M. Iqbal, "Removal and recovery of heavy metals from aqueous solution using papaya wood as a new biosorbent," Separation and Purification Technology, vol. 45, no. 1, pp. 25-31, 2005.

[11] E. N. El Qada, S. J. Allen, and G. M. Walker, "Adsorption of methylene blue onto activated carbon produced from steam activated bituminous coal: a study of equilibrium adsorption isotherm," Chemical Engineering Journal, vol. 124, no. 1-3, pp. 103-110, 2006.

[12] M. H. Nasir, R. Nadeem, K. Akhtar, M. A. Hanif, and A. M. Khalid, "Efficacy of modified distillation sludge of rose (Rosa centifolia) petals for lead(II) and zinc(II) removal from aqueous solutions," Journal of Hazardous Materials, vol. 147, no. 3, pp. 1006-1014, 2007.

[13] H. Freundlich, "Ueber dye adsorption in loesungen," International Journal of Research in Physical Chemistry \& Chemical Physics, vol. 57, pp. 385-470, 1907.

[14] V. S. Mane, I. Deo Mall, and V. Chandra Srivastava, "Kinetic and equilibrium isotherm studies for the adsorptive removal of Brilliant Green dye from aqueous solution by rice husk ash," Journal of Environmental Management, vol. 84, no. 4, pp. 390400, 2007.

[15] M. M. Dubinin and L. V. Radushkevich, "Evaluation of microporous materials with a new isotherm," Doklady Akademii Nauk SSSR, vol. 55, pp. 331-337, 1947.

[16] Y. A. Aydin and N. D. Aksoy, "Adsorption of chromium on chitosan: optimization, kinetics and thermodynamics," Chemical Engineering Journal, vol. 151, no. 1-3, pp. 188-194, 2009.

[17] S. Lagergren, "About the theory of so called adsorption of soluble substances," Kungliga Svenska Vetenskapsakademiens Handlingar, vol. 24, no. 4, pp. 1-39, 1898.

[18] Y. S. Ho and G. McKay, "The kinetics of sorption of divalent metal ions onto sphagnum moss peat," Water Research, vol. 34, no. 3, pp. 735-742, 2000. 
[19] W. J. Weber and J. C. Morris, "Kinetics of adsorption on carbon from solution," Journal of the Sanitary Engineering Division, vol. 89, no. 2, pp. 31-59, 1963.

[20] J. M. Smith and H. C. Van Ness, Introduction to Chemical Engineering Thermodynamics, McGraw-Hill, Singapore, 4th edition, 1987. 

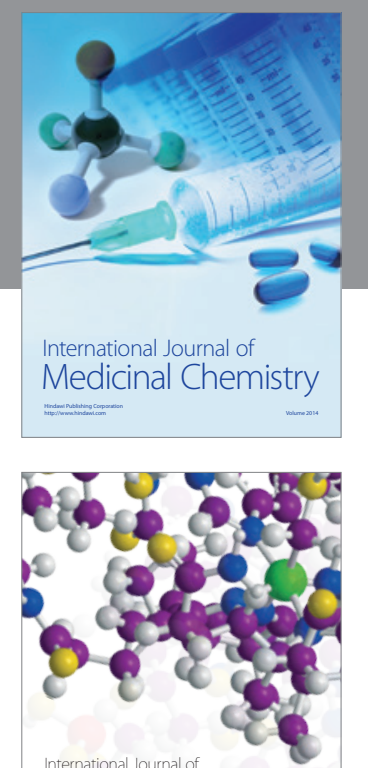

\section{Carbohydrate} Chemistry

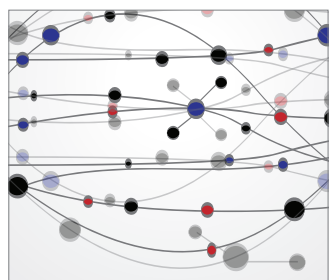

The Scientific World Journal
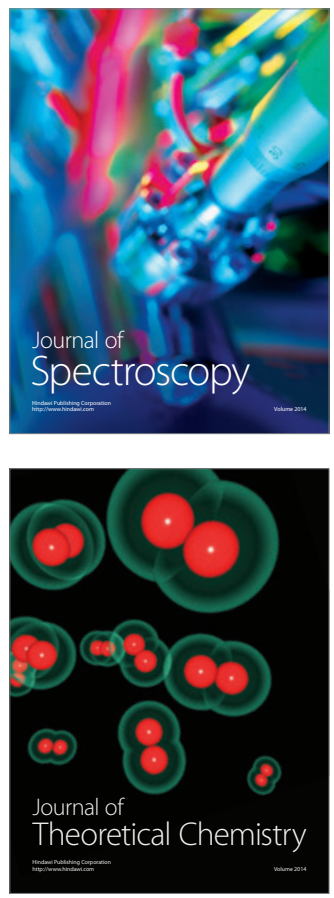
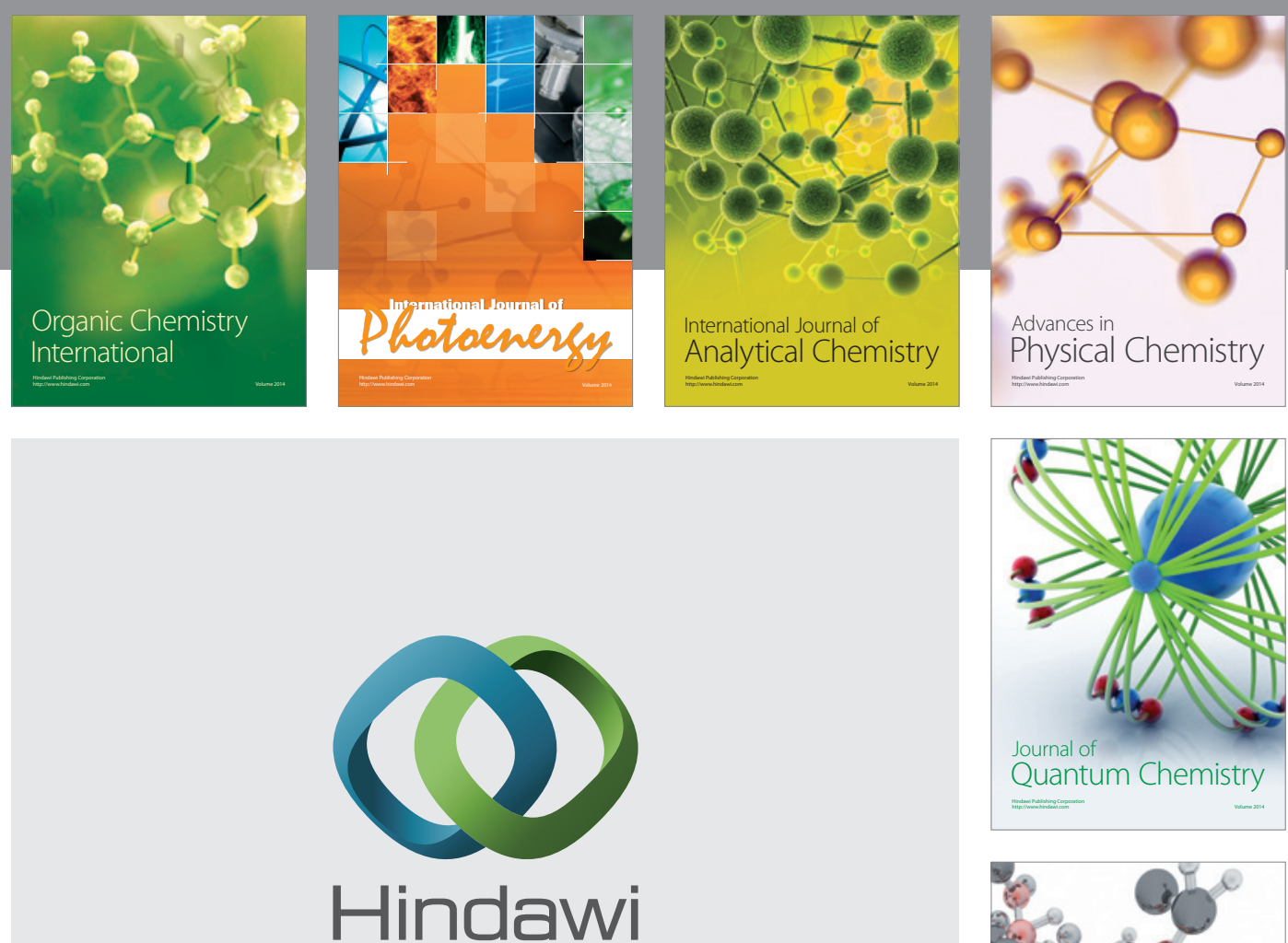

Submit your manuscripts at

http://www.hindawi.com

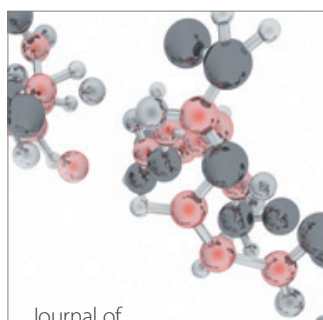

Analytical Methods

in Chemistry

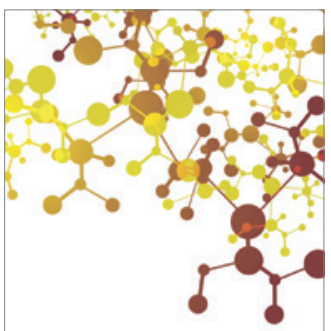

Journal of

Applied Chemistry

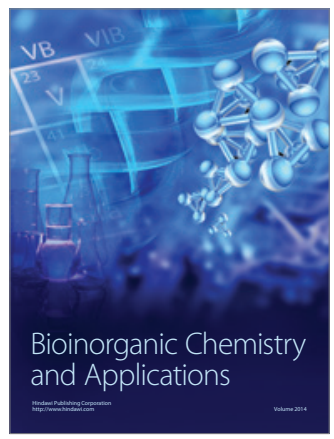

Inorganic Chemistry
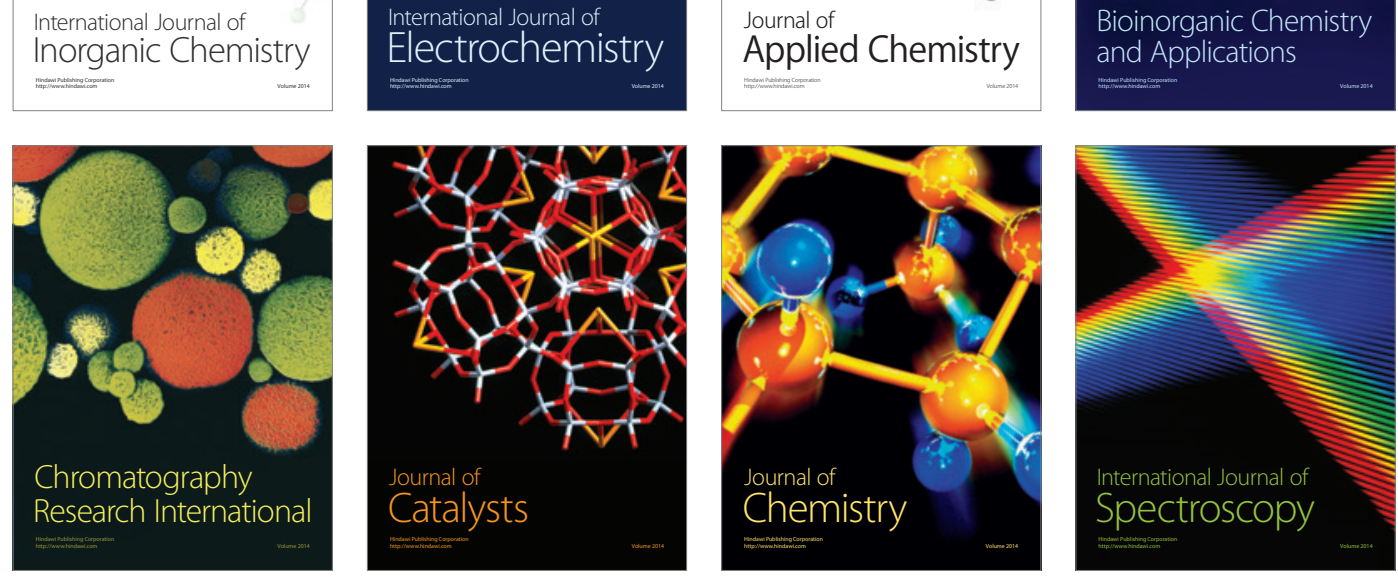